\title{
DYNAMIC REGIONAL POLITICAL CONCEPTS AND THE EUROPEAN INTEGRATION PROCESS
}

\begin{abstract}
Miloš Petrović ${ }^{1}$
Abstract: This paper aims to explore the evolution of different political constructs in the context of several EU enlargement rounds. The research has shown that the deepening of the EU integration processes has resulted in different political conceptualizations of European regions. Whereas the political notion 'Central and Eastern Europe' included countries that were part of the enlargement rounds between 2004-2007, a new political concept - the 'Western Balkans' - largely grouped the countries lagging behind in the EU integration process. However, that political concept is temporary since once a country joins the EU, it is no longer politically regarded as a 'Western Balkan' nation, as seen on the example of Croatia. The author hypothesizes that the concept 'Western Balkans', which overlaps with the EU enlargement agenda, will become outdated as a political bureaucratic term at a distant point when the entire region joins the Union. At that point, the region will be subjected to fundamentally different normative, political, economic and other contexts, which will affect how the citizens, institutions and states act, how they perceive their country, and how the international community understands and treats them in regional terms. The future abandoning of the 'Western Balkan' political concept is analyzed through the social constructivist approach.
\end{abstract}

Keywords: Western Balkans, Central and Eastern Europe, integration, EU, political constructs.

\footnotetext{
${ }^{1}$ Research Fellow, Institute of International Politics and Economics, e-mail: milos.petrovic@diplomacy.bg.ac.rs

The paper presents findings of a study developed as a part of the research project "Serbia and challenges in international relations in 2020", financed by the Ministry of Education, Science, and Technological Development of the Republic of Serbia, and conducted by Institute of International Politics and Economics, Belgrade.
} 


\section{CENTRAL AND EASTERN EUROPE: DISTANCING FROM THE "SOCIALIST PAST"}

Following the revolutionary 'Annus mirabilis' of 1989 and the abandonment of the socialist system, the rapprochement process between the former Warsaw Treaty Organization countries and the European Communities commenced (Jović-Lazić, 2015, pp. 156-157). As part of their 'return to Europe', the entire east-central region started to distance from the 'Eastern European' socialist-era legacy. 'Central and Eastern Europe' (CEE) became a dominant geopolitical regional designation in the context of European integration (Schimmelfennig, Sedelmeier, 2005, p. 2).

Whereas the Carpathian, Baltic and western Black Sea countries had initiated their European Union (EU) accession processes as part of the new Central and Eastern Europe concept, on the other hand, the EU has conceived an additional political designation: the 'Western Balkans' (Zöpel, 2018, pp. 2-3; Đukanović, Minić, 2015, p. 11). Throughout the Cold war, the term Balkans was largely geographical, its countries belonging to different strategic realities (Greece to the European Communities, Bulgaria to the Warsaw Pact, the SFRY to the Non-aligned movement, Albania - self-isolated). However, following 1989, countries like Bulgaria, previously perceived as Eastern European, in geopolitical terms became more associated with the wider notion of CEE. Although geographically placed in the 'eastern Balkan' area, Bulgaria or Romania were never politically grouped under such designation by the EU. They were instead included in the EU enlargement agenda, which treated CEE as a large cluster, consisting out of the former 'Warsaw Pact' countries. There was simply no conceptual need to set a few 'eastern Balkan' states apart from other EU candidates or distinguish them in a more specific way. The entire CEE area has joined the Union between 2004-2007 (Rapacki, Prochniak, 2009, p. 3). ${ }^{2}$

Whereas the fall of the Iron Curtain enabled countries like Bulgaria to be increasingly less associated with the term 'Balkans', that notion maintained politically relevant in western areas of the Peninsula, which was

\footnotetext{
${ }^{2}$ In their report for the EC, R. Rapacki and M. Prochniak classify the following ten states as CEE: Bulgaria, Romania, the Czech Republic, Estonia, Hungary, Latvia, Lithuania, Poland, Slovakia, and Slovenia.
} 
included in the EU enlargement policy only later. ${ }^{3}$ The region which would later become known as the 'Western Balkans' (WB) has been de facto excluded from the wider integrative processes in CEE, above all due to its political unreadiness or unfitness to enter the integrative processes in the early 1990s. The countries which lagged behind CEE in the EU integration processes included Albania and most of the former Yugoslavia. Unlike the CEE countries that joined the EU between 2004-2007, the WB countries were subjected to the Stabilization and Association Process, which included provisions directed towards encouraging the post-conflict recovery and development of good neighborly relations among the previous contenders (Džankić, Keil, 2019, p. 181). Since the accession process of the WB developed somewhat differently comparing to the CEE enlargement rounds, the EU opted to design and treat it as a separate regional political concept.

These countries' EU accession perspective was recognized at the 'EUWestern Balkans Thessaloniki Summit' in 2003, which formally marked the beginning of their long transformation process. ${ }^{4}$ As of 2020 , the only group member which successfully joined the EU was Croatia in 2013 and therefore ceased to be treated as part of the 'Western Balkans' political concept. As Theresia Töglhofer noted on that subject:'...Croatia itself now has the right to participate in decision-making in all policy areas, including the EU's enlargement policy towards the accession candidates in the Western Balkans, whose ranks it so recently left' (Töglhofer, 2013, p. 5).

While the EU ceased to perceive and treat Croatia as a WB country, the country's changed geopolitical, economic, and other position has also distanced it from that region. That represents an illustrative example of how the geopolitics and integrative processes also affect the external perception and regional 'affiliation' of the country. Likewise, the Croatian distancing from the WB political concept also resembles the preceding candidates' distancing from the Eastern European political image (Todorova, 2006, pp. 276-277). ${ }^{5}$

\footnotetext{
${ }^{3}$ The Council of the European Union. (2003). Thessaloniki European Council 19 and 20 June 2003 Presidency Conclusions 11638/03, 1 October (Council of the European Union, Brussels).

${ }^{4}$ Ibid.

${ }^{5}$ In 1994, the State Department officially abolished the designation "Eastern Europe" in favour of the CEE concept. See: Maria Todorova, Imaginarni Balkan, XX vek, Beograd, 2006, pp. 276-277.
} 
Having in mind the aforementioned, several hypotheses can be tested. The 'Western Balkans' is a temporary political notion, almost equivalent to the current enlargement agenda. As such, it will progressively lose its conceptual, political and other purposes once the candidates join the EU. Hypothetically, the current 'leading candidates', Serbia and Montenegro, may accede to the EU already during the third decade of the $21^{\text {st }}$ century, following the conclusion of prolonged accession negotiations. Following their EU accession, the 'Western Balkans' would be reduced down to a couple of 'enclaved' countries, which will further weaken the connectivity and functionality of that political domain. The Europeanization process will encourage further transformations which, in an optimistic scenario, would reshape the entire southeast European region and result in its EU membership within several decades.

However, as each new country joins, the new political, economic, institutional, and social context would distance it from the WB region to which it previously 'belonged'. That will further diminish the scope, the functioning and the political and other meaningfulness of the political concept of the Western Balkans that would become outdated by the time all candidates achieve EU membership. Once that happens, these countries would have the opportunity to deepen cooperation with other member states within regional concepts that are not limited to the western area of the Peninsula. That includes possibilities for further regional cooperation not only within CEE but also with other regions, which would be facilitated by the shared EU political, economic, and social space.

\section{THE 'WESTERN BALKANS' AS A POLITICAL CONSTRUCT - A THEORETICAL APPROACH}

Since the early 2000s, the EU has chosen to distinguish and treat the 'Western Balkans' differently from the politically more advanced 'CEE' region. Apart from the delayed onset of the European integration process, compared to their CEE neighbors, the WB was also faced with specific difficulties related to its post-conflict heritage, weaker democratic and economic performances, political challenges, etc. (Vachudova, 2019, p. 78).

Although the former Yugoslavia did not put a large emphasis on its Balkan background during the Cold war, the majority of its successor states 
and Albania were still 'identified' as such by various international actors during the 1990s (Todorova, 2006, p. 130). Their entanglement in a series of ethnic and political conflicts, economic mismanagement and other negative aspects have 'reactivated' the stereotypical political notion of the Balkans as a troubled place and Europe's 'powder keg' (Zöpel, 2018, p. 2). Since the early 20th century, the term 'Balkans' has had an unfavorable reputation due to the above-mentioned analogies with conflicts, ethnic distrust, and complex historical circumstances. The derivative term 'Balkanization' has been used pejoratively, designating the processes of uncontrolled and hostile fragmentation into smaller units (Todorova, 2006, pp. 98-99). Notwithstanding that the Balkans would remain a physicalgeographical term, and having in mind the traditionally unfavorable perceptions, it is unsurprising that the EU designated its regional approach as the 'Western Balkans'. In strategic terms, the EU no longer considers members like Croatia or Bulgaria to be part of the region anymore. Although geography has not changed, the political, economic and strategic circumstances did construct another reality.

According to the social constructivist approach, how things are named or 'labelled' influences the articulation of one's identity. The social constructivist reality is not fixed but ever-evolving, and so are its dominant terms and meanings (Theys, 2017, pp. 36-37). Notions are always connected with the values, beliefs, or more generally, the ideational context (Ibid). Institutions and the political actors may conduct separate activities, but they are intertwined and jointly shape the constructivist reality. In that context, the constructs such as 'CEE' or 'WB' are not purely bureaucratic terms, but also political inventions of various actors (EU), which attribute meanings to these concepts. Likewise, subjects subjected to those meanings are expected to act according to the construct. However, once these notions become outdated, other constructs may assume dominance.

For example, the 'Warsaw Pact' nations used to/be associated with the Soviet-style policies, socialist legacy, and Eastern-European image. Since their inclusion in the European integration process, they have been collectively regarded as the Central and Eastern Europe countries (Weise, Bachtler, Downes, McMaster, Toepel, 2001, p. 15). Over the past decade, the notion of 'CEE' has become associated with consolidated democracies that have successfully transformed their systems and satisfied the conditions to join the EU since the 2000s (Stephens, 2019). Today these countries' 
political, economic and other identities are largely influenced and shaped by the 'European' ideational factor, stemming from their EU membership.

On the other hand, the WB is a post-conflict region, subjected to the Europeanization process in the institutional, economic and political sphere (Džankić, Keil, 2019, p. 3). Having in mind the unfavorable reputation attached to the term 'Balkans', the WB notion also depicts the region as the one that is 'under construction', oriented towards (eventual) EU membership. Once the entire 'construction' process is completed and the country becomes an EU member, it ceases to be subjected to the 'Western Balkan' approach, as seen in Croatia. Therefore, it could be expected that once the leading candidates (e.g., Serbia, Montenegro) join the EU, they would begin to be perceived as part of the successfully reformed CEE. Their geopolitical position will politically 'evolve' to the EU status. However, the 'Western Balkans' would be additionally reduced to the remainder of the 'unintegrated' Southeast (Jovic, 2012, pp. 177-178).

One of the main working assumptions in this paper is that the 'Western Balkans' might vanish as a political concept once the entire current enlargement group enters the EU. Such assumptions could be backed by the preceding examples of Croatia or Bulgaria, which have been largely placed out of the Balkan-related policies. Likewise, Serbia, similarly as Croatia or Bulgaria, would one day begin to be perceived as a successfully reformed and integrated CEE country. By virtue of continuous and deep integration processes in the EU space, the country would be drawn towards forging closer ties with other member states as its new closest partners. Regional initiatives, such as the Craiova Group (which currently assembles Greece, Bulgaria, Romania and Serbia) may become important stepping stones towards the further deepening of cooperation.

The language can have a pivotal role in designing or altering social reality (Theys, 2017, p. 38). According to Wittgenstein and Winch, the role of the language is not only to (passively) reflect social reality, but also to take part in constructing that reality (Đorđević, 2016, p. 34). How we perceive or name things or act upon those considerations affects our relations. This also applies to the political actors. The EU perceives, designates and treats the region under the 'Western Balkan' approach. The term is political and bureaucratic, setting the scope for specific EU policies (Theys, 2017, p. 38). It is also structural, since it designs areas for institutional and political cooperation between the two sides (Ibid). The WB, apart from Turkey, is 
currently the sole focus of the EU enlargement policy. The enlargement policy, in constructivist terms, can be viewed as a process during which an external country, through the accession process and associate status, gradually acquires norms, values and customs of the EU. In the early 2000s, the Western Balkan countries were officially removed from the 'external relations' and included into the 'enlargement' policy, which aims to fully integrate the region. ${ }^{6}$ The successful and complete adoption of the EU model would ultimately result in the WB countries' EU accession. The WB would then formally blend into the EU area and its supranational political concept in various domains (Petrović, Radaković, 2013).

The constructivists also argue that the normative framework turns into reality once it gets accepted by the group through several distinct stages, such as the norm emergence, norm acceptance and the norm internalization (Theys, 2017, pp. 38-39; Tsvetkova, 2010, pp. 57-58). That is precisely how the EU enlargement process has been unfolding. The candidates are initially required to design and adopt legislation and shape the institutional framework according to the EU matrix in a way which would be conducive for successful and sustainable implementation. Further on, the emphasis is on the acceptance, on the enforcement of the norms, standards and values, and on removing or adjusting challenging domains which hinder comprehensively successful enforcement. The third and final stage applies to the internalization, whereby individuals and institutions have integrated the imported EU norms and values into their behavior and functioning. At that point the country becomes sufficiently 'Europeanized' and prepared to assume EU membership obligations. The accession is viewed as a valuebased contract between the candidate and the EU that share organizational principles and norms (Tamvaki, 2008, p. 62). The member states and their populations are integrated into one common political and economic system and are closely drawn together, as they function according to the same legislation, standards and values. Likewise, belonging to such a space also provides an additional confirmation of their country's 'Europeanness' (Tsvetkova, 2010, p. 59). On the other hand, the 'outdated' Eastern European

${ }^{6}$ The Council of the European Union. (2006). Brussels European Council 14/15 December 2006 Presidency Conclusions 16879/1/06, 12 February 2007 (Council of the European Union, Brussels). 
or Western Balkan constructs would remain tied to the preceding stages of political history.

According to the constructivist theory, social norms not only influence behavior and activities, but also shape how institutions work and how the identity is perceived (Aydin-Yilmaz, 2014, p. 65). Collective understanding of one's role and identity takes part in shaping the actor's considerations and activities. Citizens from the WB region will eventually become EU citizens, and their individual and national self-identification will be influenced by that fact. Once a country accedes to the EU and obtains access to a variety of freedoms, rights and obligations that will constitute a major change comparing to the current status. By doing so, the Western-Balkan 'transitory' regional identity would gradually dissolve as each new country enters the EU.

Although the EU context largely influences and shapes social reality, it does not exclude some additional, sub-regional level of political identification. The formerly WB countries may someday decide to additionally deepen regional ties within the $\mathrm{EU}$; how they name that cooperation will also influence how they perceive themselves or how they wanted to be perceived externally. Perhaps an entirely new phrasing should be used to reflect their changed status at that point. If we presume that the 'Western Balkans' is a temporary designation, applicable during the enlargement process, it would perhaps be useful to reflect a bit on how we wish to be perceived in the future or how we think we would perceive ourselves.

The Balkans is gradually losing its purpose as a political designation. Currently, it is narrowed down to the western area of the Peninsula, from which Croatia has seceded by entering the EU, diminishing its geographic scope even further. As part of its 'departure', Croatia (as other acceding members before) also withdrew from the CEFTA (Central European Free Trade Agreement). The CEFTA simulates many aspects of the EU market and is limited primarily to the 'Western-Balkans', so it would also lose its purpose once the enlargement process completes (Petrović, 2019a, p. 67). Notwithstanding the distance of the membership perspective, the regional countries will no longer be politically associated with the WB nor economically with the CEFTA. In other words, the political status of the WB and its economic area (exemplified by the CEFTA) are largely transitory and will cease to be in political use once the region, at some distant point, enters the EU. 
The European narrative becomes growingly important as the integration process progresses and constructs how the region will be referred to. In line with the constructivist logic that there could be multiple identity layers, the EU membership does not preclude the existence of regional identities (Arežina, 2013, p. 91). Even the 'Europeanization' itself is a constructivist term; literally speaking, the entire WB is indeed geographically European. However, although they originated and expanded from Western Europe, the European Communities have always perceived themselves as the core of the continent and its identity. Their governing liberal norms and values - the four freedoms, the protection of minorities, the rule of law, independent judiciary - were 'exported' into CEE and the WB as part of their integration processes with the EU (Panebianco, 2006, p. 139). The EU has not only expanded its territory but also its system of beliefs, meanings, and its sole credo towards the eastern part of the continent (Vukčević, 2013, p. 48). As of 2020, the 27 member states jointly decide on political, economic and many other aspects of reality in the Union, and the process of EU enlargement, despite deficiencies and stagnation, is formally incomplete without the 'Western Balkans'.

Whereas the 'Western Balkans' represents a current conceptual designation for still-unintegrated southeastern Europe, as the enlargement agenda gradually completes, the countries would likely be faced with the necessity to cooperate with EU partners more closely through different frameworks. Unlike the WB designation - which was unsolicited by the region but rather bureaucratically imposed by the EU - the Southeastern European countries may opt to actively take part in constructing their new political identity within the Union. That would provide an opportunity for the constructivist logic, whereby the identities are representations of actor's understandings who they are, point out to their interests, and how they mean to address them (Theys, 2017, p. 37). Politically speaking, the countries could 'evolve' from the WB associate membership to some new status, which would be more compatible with its obtained EU membership. The V4 is an example of an additional layer of political identity which has almost become politically synonymous with the Central European region. That initiative has been very beneficial as a supportive network for deepening the political, economic, cultural, and other processes as part of the wider European integration efforts. Likewise, it was also in accordance with the broader aim of reestablishing a distinctive regional Central 
European concept as a counterbalance to the abandoned socialist legacy and the outdated 'Eastern-European' image (Labov, 2019, p. 63).

From the social-constructivist perspective, names are symbolically powerful and may reflect how we perceive our position and how the world perceives us. If the 'Western Balkan' notion indeed loses its political purpose once the enlargement agenda is realized, the author finds it relevant to consider the changed political perceptions which might reflect the new position and our adjusted understanding of who we have become. The new political concept which could illustrate an ideational shift from the postconflict WB towards a CEE/EU 'status' may be connected with participation in some other regional partnerships. Once the region, mostly or in its entirety, joins the EU, there might be new proposals for reconnecting the southeastern European area. In constructivist terms, it might be relevant to consider several naming proposals that might be suitable for an initiative that would cover the southeastern European states and reflect distancing from the externally named, growingly outdated bureaucratic notion known as the 'Western Balkans'.

\section{EU MEMBERSHIP - A POLITICAL IDENTITY CHANGER}

Deepening cooperation within older or newly established regional initiatives may mark a shift away from the 'Western Balkans' as a political concept, especially once Serbia becomes the EU member. At that point, the political paradigm shift will materialize in a twofold manner. Firstly, the EU will cease treating Serbia within the WB approach and instead will act in accordance with all membership-related norms and privileges. The application of the conditionality principle will change, and the country would participate in the decision-making and shaping of policies along with other member states. Secondly, the position of the country will fundamentally change, both internally and externally. Externally, it will be treated as a member of the world's most prosperous market and political area, instead of belonging to the enlargement group - the 'Western Balkans'. Internally, the EU norms, regulations, standards and benefits will integrate the country fully into the Union and largely reshape the political, economic, and social context. The new 'sense of belonging' will even be symbolically represented by means of an EU passport. On the other hand, the political 
concept of the 'Western Balkans' will no longer be applicable in its original form. This may lead to the consideration of the new regional initiatives, which could reflect the newly acquired, upgraded strategic position of the country, and (perhaps also) its changed self-perception.

In constructivist terms, the EU is a non-traditional international actor, which defines its own modes of functioning, and its legislative, political and other activities provide valuable insight into its self-identification and the perception of its international role (Vukčević, 2010, p. 204). Its institutions, member states and citizens accept and adhere to the EU norms, standards, and values. The deepening and widening of the European integration have contributed to the 'Europeanization' of its member states and the acceptance of an additional, supranational level of identity in a variety of domains (Ibid, p. 205). These processes encourage constant approximation between countries that shape the 'European project' and contribute to the sense of common belonging (Aydin-Yilmaz, 2014, p. 56).

This feeling of belonging to a common area is visible in many domains. The EU single market operates as an internal market, with the free mobility of people, goods, services, and the capital. These four freedoms constitute the governing ideas and the very backbone of the entire EU integration process. Freedom to work across the Union, guaranteed by the Treaties, consists one of the most enjoyed benefits of EU citizenship (EP, 2020). ${ }^{7}$ Likewise, since 1979, the EU citizens vote for their representatives in the European Parliament (Cracknell, Morgan, 1999, p. 7). Through the ordinary legislative procedure, along with the Council of the European Union, the Parliament adopts legislation that subjects the entire EU territory to the same norms. These norms are applied in each member state and encourage further 'Europeanization' processes in each country. Although sovereign prerogatives are still very strong, especially in high political domains, the member states are expected to comply with the decisions of supranational institutions in many areas and to apply the acquis, which facilitates further bonding between the states, institutions, and individuals within the EU territory.

The continuation of the EU accession process in the following decades provides room for the emergence of the new regional initiatives, or the

\footnotetext{
${ }^{7}$ Legal basis: Article 3(2) of the Treaty on European Union (TEU); Articles 4(2)(a), 20, 26 and 45-48 of the Treaty on the Functioning of the European Union (TFEU).
} 
expansion of the already existing ones. Hypothetically, the existing platforms for political cooperation, such as the Visegrád Group (consisting of Czechia, Slovakia, Hungary and Poland) may include new countries. However, this political alliance was established as a coordination platform in the context of the integration processes and did not expand geographically since its establishment 25 years ago (Đukanović, Minić, 2015, p. 25). Whereas the V4 might never expand, it might offer space for eventual privileged cooperation with other countries/regional initiatives.

However, the Craiova Group (CG), in which Serbia already takes part alongside Bulgaria, Greece and Romania - may gain additional prominence as an internal EU regional cooperation platform once Serbia enters the Union. The CG, which currently focuses on expanding possibilities for cooperation in the domains of infrastructure, energy and EU integration, largely resembles the V4 initiative. At this development phase, it focuses largely on interconnectivity and aims to upgrade the underdeveloped domains of cooperation and overcome the economic and other disparities (Bochev, 2018). The CG is currently asymmetrical with Serbia as the sole non-EU member, but it could eventually evolve into another inter-EU regional framework. The CG members are not only neighbors but also close economic and political partners that share common historical and cultural traits. Initiatives such as the CG may become one of the pivotal regional cooperation platforms for Serbia, not only as it currently benefits its EU membership ambitions, but also because once the country joins, it will already have a developed framework of cooperation - a close and 'friendly' domain - for further projects.

Likewise, there could be opportunities to establish a new regional cooperation model. Such a platform may also reflect the changed context and the new understanding of the country's changed political reality and identity. In some distant future, once the entire WB area accedes to the EU, the possibilities for reestablishing mutual cooperation may be realized in a different political, economic and social context.

From the contemporary practice, it may be drawn that the 'baptizing' of the regional initiatives is often tied to some geographical and historical scope, which may reflect the common feeling of belonging or assert certain identity, such as Central-European within the V4 initiative (Jagodzinski, 2006). The V4 was named after a medieval alliance between the leaders of the above-mentioned nations, forged in the Visegrád castle. However, in the 
WB area, domains such as history or culture constitute a challenging 'least common denominator', having in mind largely fragmented and diverging historical interpretations. Therefore, some neutral geographical designation may be more appealing and be broad enough to bridge the differences and accommodate different perceptions. These may be named after mountain ranges (Dinaric Alps, Haemus Mons), or by the rivers (e.g., Sava/Drina...), depending on the geographical scope. Naming after toponyms, given the history and the diverging perceptions in the region, may prove to be less controversial, divisive or neutral comparing to, for example, bearing the name of some regional historical personality or event which could be interpreted in diverging ways in different countries. For example, the archaic Hellenic term for the Peninsula - Haemus could still apply, partially or fully, to the Balkans (Todorova, 2006, p. 79). Although outdated, selecting such a name for some political regional platform would represent a symbolic tribute to the Hellenic culture and political thought, which is native to the region. It would also be helpful in "constructing" or reshaping a new regional political idea, following the disestablishment of the WB political concept.

The author would also suggest exploring neologisms such as the Dinaric Group. The Dinaric Alps stretch across the region in the northwest-southeast direction. That is a neutral term which, like the Balkan designation, depicts a mountainous nature of the region. Unlike the Balkans, the term is not burdened by the negative prejudice, political or ideological stances and propaganda, which often depict it as a region inclined towards violence, conflicts, ethnic distrust, fragmentation, nationalism, backwardness, transcultural clashes, etc. The term 'Dinaric Group' is neutral, unhindered by historical, political and social inputs, and as such might be useful for depicting their development from the 'Western Balkan' status to some upgraded form of cooperation, which would reflect the context of their EU membership prospects.

Similarly to the V4 or the $\mathrm{CG}$, and unlike the WB concept, such platforms may be initiated 'from below', by the regional governments. Apart from supporting European integration efforts, their value is in fostering sustainable and deeper cooperation. The V4 was established to coordinate regional integration efforts, which was perceived favorably for their EU membership prospects. (Paroubek, 2006, p. 14). These countries perceived themselves as Central European, whose political identity is related to and interested in adopting the 'Western' system and norms. These perceptions 
are in accordance with the constructivist view that countries striving towards a certain identity should adhere to the norms that form that identity (Theys, 2017, p.38). The establishment of a regional platform was perceived as a supportive instrument in acquiring ideas, norms, models, and other aspects which build the EU political identity. Following the EU accession, the V4 successfully continued its political and social mission in Central Europe (Paroubek, 2006, p.14). For the V4 countries, the EU membership provided an additional incentive for deepening regional cooperation, as it resulted in access to the single market, set of fundamental freedoms, rights, obligations and benefits which further removed formal barriers in forging even closer regional ties.

\section{Concluding remarks}

Many years ago, the 'Western Balkans' entered the process of European integration. Although Serbia and Montenegro are commonly perceived as the upcoming two member states, the EU accession process is stringent and prolonged, as these candidates struggle to meet demanding requirements in fundamental areas of the rule of law, the independence of the judiciary and high political domains (Petrović, 2019b, p. 31). Although these candidates might not meet the ambitious deadlines set by the Credible enlargement strategy in 2018, their EU membership remains a proclaimed strategic goal and should be expected, perhaps already by the end of the decade (Petrović, 2019a, pp. 72-73).

On the one hand, it might be somewhat optimistic to already project the future of the WB concept once the 'leading candidates' become fully 'Europeanized' and join the EU. However, it appears likely that in such a case, by the virtue of their new geopolitical, economic and other position and the new modus operandi, these countries would be encouraged to proceed with the integration processes with the remainder of the EU. The future EU territory in Montenegro and Serbia would reduce the 'Western Balkans' and divide it into two parts, marginalizing it even further as a political and economic concept. The functioning of the CEFTA within such 'enclaves', intersected by the EU territory, would be additionally challenged. The 'Western Balkan' area would thus become additionally fragmented (or ironically speaking, 'Balkanized') while countries like Serbia would integrate 
further with EU partners, which would progressively distance it from the WB concept.

Taking part in regional initiatives may also reflect how these countries perceive themselves or want to be perceived, especially once the EU membership is obtained. At that point, the political identity will be affected both internally and externally. The shared EU political, economic and social space will stimulate the deepening of ties and facilitate new modes of regional cooperation. Initiatives such as the Craiova Group may become one of the pivotal regional cooperation platforms for the Republic of Serbia, not only as a platform for advancing its EU membership prospects but also as a domain for closer regional cooperation with (other) EU members. The importance of such networks should not be underestimated, especially during the post-EU accession period, when the country might need new regional partnerships.

\section{BIBLIOGRAPHY}

Arežina S. (2013). European identity, in: P. Petrović \& M. Radaković (Eds.), National and European identity in the process of European integration, (pp. 91-92). Belgrade, Institute for International Politics and Economics.

Aydin-Yilmaz, S. (2014). Political Identity Building in the EU: A Constructivist Approach, Journal of Academic Inquiries, 9(1), p. 65.

Bochev, V. (2018, December 6). Craiova Group - too late or better late than never?, retrieved from: https://cep.org.rs/en/blogs/craiova-group-toolate-or-better-late-than-never/. Accessed 10 August 2020.

Council of the European Union. (2003). Thessaloniki European Council 19 and 20 June 2003 Presidency Conclusions 11638/03, 1 October (Council of the European Union, Brussels).

Council of the European Union. (2006). Brussels European Council 14/15 December 2006 Presidency Conclusions 16879/1/06, 12 February 2007 (Council of the European Union, Brussels).

Cracknell, R, Morgan, B. (1999). European Parliament Elections - 1979 to 1994, House of Commons Research Paper, 99(57), p. 7.

Džankić, J, Keil S. (2019). The Europeanization of Contested States: Comparing Bosnia-Herzegovina, Macedonia and Montenegro, in: J. 
Džankić, S. Keil \& M. Kmezić (Eds.), The Europeanisation of the Western Balkans: A Failure of EU Conditionality?, (pp. 3-183). Cham, Palgrave Macmillan.

Đorđević, V. (2016). US Foreign Policy in the Western Balkans from 1993 to 2009. Brno, Masaryk University.

EP. (2020). Free movement of workers - Fact Sheets on the European Union. European Parliament, retrieved from: https://www.europarl.europa.eu/ factsheets/en/sheet/41/free-movement-of-workers\#: :text=Freedom \%20of\%20movement $\% 20$ for $\% 20$ workers $\% 20$ has $\% 20$ been $\% 20$ one $\%$ 20 of $\% 20$ the,within $\% 20$ the $\% 20$ European $\% 20$ single $\% 20$ market. Accessed 20 August 2020.

Jović, D. (2012). Hrvatski referendum o članstvu u Europskoj uniji i njegove posljedice za smanjeni Zapadni Balkan [Croatian Referendum on European Union membership and its Consequences or the Reduced Western Balkans], Annals of the Croatian Political Science Association, 9(1), pp. 177-178.

Jović-Lazić, A. (2015). Odnosi između Evropske unije i Ruske Federacije - kraj XX i početak XXI veka [Relations between the European Union and the Russian Federation - the end of the 20th and the beginning of the 21st century]. Beograd, Institut za međunarodnu politiku i privredu.

Labov, J. (2019). Transatlantic Central Europe: Contesting Geography and Redefining Culture beyond the Nation. Budapest, Central European University Press, p. 63.

Minić, J, Đukanović, D. (2015). Fifteen Years of Preparations for Preaccession Negotiations in Serbia, in: J. Minić, European integration of the Western Balkans - can the Visegrad Group countries serve as role models?, (pp. 25-30). Belgrade, Research Forum.

Panebianco, S. (2006). Constraints on the EU as "norm exporter", in: 0. Elgström, M. Smith (Eds.), The European Union's Roles in International Politics: Concepts and Analysis, (pp. 139-140). London, Routledge.

Paroubek, J. (2006). Višegrad Group celebrates its fifteenth anniversary, in: A. Jagodzinski, The Visegrad Group: A Central European Constellation, (pp. 1-14). Bratislava, International Višegrad Fund.

Petrović, M. (2019). EU integration process of Serbia: a vicious circle of high politics, Review of International Affairs, LXX(1175), p. 31. 
Petrović, M. (2019). Izmenjena politika proširenja: izazovi i koncentrični krugovi integracije [The altered enlargement policy: challenges and concentric circles of integration], Međunarodni problemi, LXXI(1), pp. 67-73.

Rapacki, R, Prochniak, M. (2009). The EU enlargement and economic growth in the CEE new member countries, Economic Papers 367(1), pp.3-4.

Schimmelfennig, F, Sedelmeier, U. (2005). Introduction: Conceptualizing the Europeanization of Central and Eastern Europe, in: F. Schimmelfennig \& U. Sedelmeier (Eds.), The Europeanization of Central and Eastern Europe, (pp.1-2). Ithaca, Cornell University.

Stephens, H. (2019, April 3). The Battle for Democracy in Central and Eastern Europe, retrieved from: https://www.worldpoliticsreview.com/ insights/25066/the-battle-for-democracy-in-central-and-easterneurope, Hampton Stephens. Accessed 30 July 2020.

Tamvaki, D. (2008). EU enlargement and public support for integration: how Europe of the elites shapes Europe of the electorates, in: K. M. Khovanova, N. Dogan \& M. Kovalev (Eds.), Expanded EU: From Autonomy to Alliance, (p. 62). Amsterdam, Rodopi B.V.

Theys, S. (2017). Constructivism, in: S. McGlinchey, R. Walters \& C. Scheinpflug (Eds.), International relations theory, (pp. 36-40). Bristol, EInternational relations publishing.

Todorova, M. (2006). Imaginarni Balkan [Imagining the Balkans]. Beograd, XX vek, pp. 98-277.

Töglhofer, T. (2013). From the West of the Balkans to the "Rest of the Balkans"? Effects of Croatia's EU Accession on South Eastern Europe, in: E. Sandschneider (ed.), DGAPanalyse, (p. 5). Berlin, Deutsche Gesellschaft für Auswärtige Politik.

Tsvetkova, S. (2010). European Identity Formation in Central and Eastern European Countries after Accession by the European Union. ASPJ Africa \& Francophonie 1(4), pp. 57-59.

Vachudova, M. A. (2019). EU enlargement and state capture in the Western Balkans, in: J. Džankić, S. Keil \& M. Kmezić (Eds.), The Europeanisation of the Western Balkans: A Failure of EU Conditionality?, (p. 78). Cham, Palgrave Macmillan. 
Vukčević, D. (2010). Spoljna i bezbednosna politika EU u svetlu socijalnog konstruktivizma [EU Foreign and security policy in the context of social constructivism], Srpska politička misao 2 17(28), Institut za političke studije, pp. 204-205.

Vukčević, D. (2013). Effects of the socialization process of Europeanization of EU member states' national identities, in: P. Petrović \& M. Radaković (Eds.), National and European identity in the process of European integration, (p. 48). Belgrade, Institute for International Politics and Economics.

Weise, C, Bachtler, J, Downes, R, McMaster, I. \& Toepel K. (2001). The Impact of EU Enlargement on Cohesion, Final report for the European Commission. German Institute for Economic research and the European Policies Research Centre, pp. 15-16.

Zöpel, C. (2018). The future of 20 million people in the six Western Balkan states. A key question for Europe's geopolitical future. Brussels, FEPSFoundation for European Progressive Studies. 